\title{
The synanthropic status of wild rock doves (Columba livia) and their contribution to feral pigeon populations
}

\author{
Natale Emilio Baldaccini
}

\begin{abstract}
Wild rock doves still breed in suitable habitats along southern and insular Italy, even if their colonies are threatened by the genetic intrusion of feral pigeons. One of their prominent behaviours is the daily foraging flights from colonial to feeding grounds which involves coming into contact with man-made buildings. These are exploited firstly as roosting places near crop resources and later for nesting. This incipient synanthropy is not extended to direct food dependence on humans, by which they tend to remain independent. In the same way that ferals genetically intruded the wild colonies, in urban habitats, rock doves mix with ferals because of the large interbreeding possibilities. In the natural range of the wild species, this has occurred since the appearance of the feral form of pigeons and still continues with the residual populations of rock doves, representing their endless contribution to the feral populations, at least until the dissolution of the gene pool of the primordial form of wild rock dove.
\end{abstract} birds.

Key words: rock dove, feral pigeon, Columba livia, synanthropic

Riassunto - Contributo dei Colombi selvatici (Columba livia) in stato sinantropico alla costituzione delle popolazioni di colombo di città.

Le popolazioni di colombo di città provengono da esemplari domestici sfuggiti al loro stato; tuttavia deve essere riconosciuto anche il contributo che ad esse ha dato il colombo selvatico, almeno relativamente al suo areale di presenza ed in particolare grazie alle sue popolazioni sinantropiche. Per questo viene qui considerato: lo stato di presenza delle popolazioni di colombo selvatico in Italia, quello delle passate e presenti popolazioni sinantropiche, i meccanismi che hanno facilitato l'insediamento dei colombi selvatici negli ambienti urbanizzati ed infine il possibile contributo di essi alle popolazioni urbane. Tale contributo non si è esaurito con la domesticazione del selvatico, ma una volta stabilitesi le popolazioni urbane di provenienza domestica, esso è continuato stante la possibilità illimitata di riproduzione tra le entità domestiche, di città e selvatiche. In tal modo, laddove queste sono in stato simpatrico, deve essere stato possibile una relazione riproduttiva continua che ha portato geni selvatici nelle popolazioni urbane altrettanto continua, specialmente laddove sono ancora presenti colonie di selvatici. Allo stesso modo geni "domestici" sono stati introdotti nelle popolazioni selvatiche, portando alla dissoluzione del pool genico originario della forma selvatica.

Dipartimento di Biologia, Università degli Studi di Pisa,

Via A. Volta 6, 56126 Pisa, Italia.

E-mail: natale.emilio.baldaccini@unipi.it

(C) 2020 Natale Emilio Baldaccini

Received: 18 May 2020

Accepted for publication: 3 June 2020

On line publication: 7 October 2020
Parole chiave: colombo selvatico, colombo di città, Columba livia, uccelli sinatropici.

\section{INTRODUCTION}

Feral pigeons are among those birds with the most developed degree of synanthropy, being one of the oldest and most common human commensal worldwide (Lever, 1987). Nevertheless, a synanthropic status may also characterize another pigeon, namely the wild rock dove ( $\mathrm{Co}$ lumba livia Gmelin, 1789), the ancestors of domestic pigeons (Darwin, 1868; Goodwin, 1970), when they leave their natural habitat to settle in the urban one to nest and live.

The primary and most important contribution to the genetic pool of feral populations is from the domestic pigeons, when they escape, are lost or abandoned by their owners (Johnston \& Janiga 1995). Nevertheless, as hypothesized for instance by Grüll (1980), this has occurred in another way, following the synanthropy of wild rock doves in human settlements, since humans create an ideal cliff-like habitat for them (Hoffman, 1982) or because the feeding resources allowed by the agricultural activity (Goodwin, 1978). The first mechanism that allowed the development of free self-sustained populations of domestic pigeons occurred everywhere. The second one, from a geographical point of view, only regards the original range of the wild rock doves, where they can interact and interbreed with feral pigeons. Nevertheless, the way synanthropic rock doves possibly contributed to feral populations is still an open question.

In effect, the genetic structure of ferals may be considered as the result of a complex crossbreed of different domestic pigeons (Stringham et al., 2012; Biala et al., 2015), but their real link with, and consequent contribution from, the pool of local domestic breeds reared in a given geographic area has never been studied in depth. Likewise, there is no genetic information relative to populations of wild rock doves, from the moment that the existence of wild populations uncontaminated by domestics or ferals is questionable (Goodwin, 1978; Stringham et al., 2012). It will therefore be difficult to investigate the genetic links between ferals and wild pigeons. Instead, the link between ferals and domestic breeds of a given area has been recently substantiated by Giunchi et al. (2020) for Northern and central Italy. 
On the other hand, the data of Johnston et al. (1988) obtained by protein electrophoresis reveal that the genetic distances from Sardinian rock doves and Italian and North American ferals are substantial. In particular, it is significant that a number of genetic loci of ferals have alleles not found in wild pigeons. While the gene flow from ferals to wild rock doves and its conservation concern have long been underlined (Goodwin, 1970; Johnston et al., 1988; Boano et al., 2018), the contribution of rock doves to feral populations is only putative (Johnston \& Janiga, 1995), being not supported by any empirical data. Nevertheless, there is no doubt that in the natural geographic range of rock dove, there has been a long history of a reproductive relationship with the ferals. Since the feral pigeon is a city dweller bird, that relationship must have most likely developed in the cities themselves and particularly with the synanthropic rock doves.

To further contribute to a better answer to the question regarding the potential way in which synanthropic rock doves contribute to feral populations, the status of synanthropy of the wild rock dove in Italy will be reviewed along with the probable role of this bird as regards the development of feral populations in a Mediterranean-Near East perspective. This is because it was in this geographic area that the rock doves were firstly tamed and domesticated (Sossinka, 1982), subsequently producing perhaps the first form of feral animal, with a history of several thousand years.

The reported data represent a synthetic review of the past and present distribution of the wild populations and synanthropic colonies of rock dove in Italy. The data sources have been both from bibliographic information and direct observations gathered over a long period of field researches on the species (1970-today). These have been devoted mainly to spatial orientation, occurrence of foraging flights and distribution of rock dove colonies, chiefly on the island of Sardinia and in the Abruzzi, Puglia and Sicily regions as well.

\section{THE STATUS OF ROCK DOVE IN ITALY}

As reported firstly by Toschi (1939) and then by the results of the Italian Atlas Project (Meschini \& Frugis, 1993; but see also Baldaccini, 2003), the species was, at those times, still common in suitable rocky habitats, both along sea and inland cliffs of the central and Southern parts of the Peninsula, in Sicily and Sardinia, as well as in the Julian Alps (Karst district) and in the Istrian peninsula (Croatia). In particular, in these latter parts, the rock doves have been frequent in the habitat of the "foibe", as reported by Toschi (1939) who presents some pictures of these shelters, which are a sort of large vertical cave opening in the calcareous substrate of the area. According to the same Author, the districts of the Venezia-Giulia region hosted the largest Italian populations at that time, with more than 20,000 individuals in the same Istrian peninsula.

Today, rock dove populations which have not experienced a degree of introgression from feral or domestic pigeons are almost certainly difficult to find in Italy, causing them to be threatened with genetic extinction (Peronace et al., 2012). This process was discussed at length in the paper by Johnston et al. (1988). Johnston (1992a) has then predicted the genotypic extinction of rock dove in the Mediterranean area within the last century, partly through hunting pressure, habitat changes and partly through genetic assimilation by ferals.

Colonies with a level of less genetic introgression might be found in Sardinia. In fact, Sardinian farmers tend not to keep pigeons because they litter rooftops that are used to collect rainwater (Johnston et al., 1988). Because populations of Sardinian ferals are restricted to large cities, rural colonies of rock doves have been relatively unthreatened. Nevertheless, now things are changing. Table I represents the number and relative percentage of pigeons trapped at a large colony of rock doves near Capo Caccia (NW Sardinia) with phenotypic signs of interbreeding with ferals or domestics visible in the feather coat (colour and/or pattern) or bare parts (colour, feathered tarsi, cere size), over successive years. With the exception of the first capture event, in the others, birds with phenotypic signs of genetic introgression were always present, with a noticeable increase in percentage in the last event. Nevertheless, the data presented could be biased both by the different number of trapped pigeons over the various years, and by the fact that interbred individuals could be more easily captured. At the same time, pigeons without visible marks of genetic introgression could be present but are impossible to detect.

In other regions of Italy, it seems evident that feral and domestic introgression has progressed even further. For instance in Sicily, where, as stated by Iapichino \& Massa (1989), wild rock doves are uncommon to fairly common, but their status is sometimes difficult to assess because of the gene flow with ferals, which are common in every town and village. Indeed, the wild individuals are extinct on the island of Ustica. The same is true for several places in the Puglia region where rock doves were present before, as in the cave of "Zinzulusa" (Lecce) or in those of Castellana, now inhabited only by feral pigeons. For the same region, scattered colonies of few individuals were reported by Liuzzi et al. (2013) for the Gargano promontory and by La Gioia (2009) for the East cost of Salento, but "in alarming status of genetic pollution" (La Gioia 2009). A rather similar situation of genetic introgression was reported by Boano et al. (1985) for the Basilicata region (Sinni river valley, "Gravine" of Brandano river, Muro Lucano, among others).

Tab. 1 - Rock doves trapped at the colonies of Capo Caccia (Sardinia) in different years bearing phenotypic signs of genetic introgression from domestics or ferals. Nt: birds trapped; Ni: introgressed specimens ( $\mathrm{n}$ and \%). / Colombi selvatici catturati nelle colonie di Capo Caccia (Sardegna) in anni differenti con segni fenotipici di introgressione di geni di colombi domestici o di città. $\mathrm{Nt}$ : numero di colombi catturati; Ni: numero e percentuale di individui introgressi.

\begin{tabular}{|r|r|c|l|}
\hline Year & \multicolumn{1}{|c|}{$\mathbf{N t}$} & $\mathbf{N i}$ & \multicolumn{1}{|c|}{ References } \\
\hline 1972 & 26 & 0 & Alleva et al., 1975 \\
\hline 1987 & 50 & $1 ; 2 \%$ & Baldaccini et al., 1988 \\
\hline 1989 & 371 & $4 ; 0,9 \%$ & Ragionieri et al., 1991 \\
\hline 1997 & 52 & $4 ; 7,7 \%$ & Baldaccini et al., 2000 \\
\hline
\end{tabular}


In this view, in the peninsular range of the wild rock dove in Italy, non-introgressed colonies have at present almost disappeared, following the prediction made by Johnston (1992a), though not through concomitant hunting pressure or habitat changes, but exclusively through genetic assimilation by ferals. In fact, in Italy, the hunting of pigeons has long been forbidden (1938), while no noticeable habitat changes interest the districts where rock doves have been present.

Putatively, Sardinia and its surrounding islets, some islands of the Tuscan Archipelago, possibly some mountains cliffs in Central Apennines, the Julian Alps, may still host the last small groups of rock doves. In the other places, the old colonies have been genetically intruded and largely substituted by the feral stocks.

\section{SYNANTHROPIC POPULATIONS IN ITALY}

In the urban habitat rock doves can find suitable places where they can roost and nest freely, especially in historical buildings, churches, towers and ancient city walls, all representing vicariant resting places with respect to natural ones. According to bibliographic information and direct experience, in towns and villages of different regions of Italy, synanthropic populations of rock doves have been described as present until the end of the $19^{\text {th }}$ century (Savi, 1829; Salvadori, 1873; Ghigi, 1950), still surviving in Southern and insular sites at least by the end of last century.

The well-known presence of these synanthropic populations to ornithologists and the common man have left different traces in Italian ornithology and, first of all, in the vernacular names used for the synanthropic ones: the so-called "torraioli pigeons". With regards to these, the late Italian ornithologist A. Ghigi said: "Rock doves and the torraioli pigeons are the same thing; the ferals are not torraioli pigeons" (Ghigi in Toschi, 1939). This means that among the pigeons living in towns there have been two distinguishable lineages: the ferals but also the synanthropic rocks or "torraioli". These birds differ from rock doves only from an ecological point of view, being in an urban habitat rather than in a wild one.

Rock doves are reported as being common in various Italian towns, such as Florence, where they nested in large numbers in several churches, like the Cathedral and the Holy Cross (Savi, 1829), or in the ancient monuments of inner Rome (Salvadori, 1873), where they were erroneously described by the prince Bonaparte (1832) as a separate species (Columba turricola). Indeed they were reported for Bologna (Ghigi, 1950) and for the town of S. Andrea Apostolo dello Ionio (Calabria) by Lucifero (1901), being described as very common in the bell-tower of the local church.

According to Savi (1829) and Ghigi (1950), the synanthropic rocks behaved differently with respect to ferals. In particular, their colonies remain independent of those of ferals, "without joining them in mixed flocks in streets and squares, preferring instead to make regular foraging flights outside the city" (Ghigi, 1950). In consequence, the same Author argued that the contribution of rock dove to feral populations was very limited. It is difficult to accept this view, since foraging flights is a common behaviour even for ferals, with an identical temporality (Soldatini et al., 2006). This means that rocks and ferals can share both the resting and also the feeding places, as we have directly observed in Sardinia for mixed groups of wild and feral pigeons. Such a relationship may have facilitated interbreeding, an event underlined indeed by Ghigi (1950) affirming that "an occasional cross may occur between the single individuals of both breeds". This affirmation is an implicit admission of the reproductive relationship, not certainly "occasional" between the two city dwellers, with the consequent bi-directional gene flow. In fact, as stated by Johnston et al. (1988), even if feral pigeons and rock doves "differ morphologically at the level of avian subspecies, and genetically perhaps at the level of species", no apparent mating barrier or inadequate reproduction between ferals and rocks was reported by Murton \& Clarke (1968). Equally, according to Burley (1981), mate choice preferences are no barrier to their interbreeding, so that the two forms of pigeons can interbreed successfully.

\section{KEY FACTORS IN PRODUCING SYNANTHROPY IN ROCK DOVES}

As granivorous birds, one of the prominent behaviours of wild rock doves in their natural habitat, is the daily foraging flights from colonial sites to feeding places, usually crop fields, vineyards or pastures as reported by Baldaccini et al. (2000). The same pattern of daily commuting flights has been reported for ferals (e.g. Janiga, 1987; Soldatini et al., 2006), which is interpreted as a common response to causal environmental and biotic factors.

As discussed by Baldaccini \& Giunchi (2006) these flights play a central role in the process of synanthropy, together with some potentially less important and not well evaluated factors such as post-juvenile dispersion or competition for nesting sites. These flights, enlarging the activity range of rock doves, bring the birds into contact with cultivated fields, buildings and, on the whole, with human activities, producing a daily change in the centre of gravity of a given colony, at least outside the restricted reproductive period of this species (Thibault \& Bonaccorsi, 1999).

The wild rocks at Capo Caccia colonial sites (NW Sardinia) must commute considerable distances from the coastal cliffs, to find food and water at least $20-25 \mathrm{~km}$ inland in different directions, according to seasons (Baldaccini et al., 2000; and unpublished data). These flights are guided by a well-developed spatial behaviour based not only on landmark recognition but even by a sun-based mechanism of compass orientation (Baldaccini et al., 2001; Giunchi et al., 2003). In fact, the rock dove has demonstrated comparable navigational capabilities with respect to homing pigeons (Alleva et al., 1975; Visalberghi et al., 1978).

As we have repeatedly observed, rock doves use buildings near their feeding grounds initially only as roosting places, returning to their colonies for the night. Nevertheless, if the food or water resources become quite stable all year round and the nearby buildings offer suitable shelters, it can be advantageous for them to settle and nest near those resources. The selective advantages of that behaviour is clear particularly in term of energy saving, drastically reducing the span of foraging flights, as well as the predation risks. In this way, towns and villages may have attracted 
rock doves, bringing them to a stable status of synanthropy, in particular when these human settlements were near rock doves colonies and within their daily range of foraging flights. As an example, inside a stone quarry $16 \mathrm{~km}$ to the East of Capo Caccia colonies, a stable water reservoir of about $300 \mathrm{~m}^{2}$ was naturally formed during the fall of 1996 . Initially, it was only used by rock doves as a watering site, but along the walls of the quarry there are a great number of suitable holes resulting from the excavating activities. In these holes a colony of no more than 20 birds settled in the subsequent spring in a stable manner.

In this form of incipient synanthropy, the relationships between pigeons and man are not extended to direct food dependence, as for ferals, but pigeons simply take advantage of the presence of food, water and shelters close by. We may regard this process as a mere change in the centre of gravity of a given group of rock doves, commuting from a natural habitat to an anthropic one, with very little change, if any, in their general behaviour.

\section{THE CONTRIBUTION OF ROCK DOVES TO FERAL POPULATIONS}

While the ferals largely originated from escaped or lost domestic breeds everywhere in the world, settling in urban habitats (Lever, 1987), the first inhabitants of towns and villages not far from natural colonies of rock doves were their synanthropic individuals. This fact is still evident today for instance in the Indian subcontinent, where also in cities such as Kathmandu (Nepal) the city pigeons are not ferals but rock doves, belonging in this case to intermedia subspecies (Fig. 1). On the contrary, in Europe, the Mediterranean and Near East countries, these first city dwellers are today largely substituted by the increasing feral populations. Nonetheless, the rock doves did not disappear but were simply genetically introgressed by domestic and feral breeds and then assimilated by these.

This is the case in the several places where we have recently observed groups of synanthropic rocks such as, for instance, in the region of Abruzzo (Opi, Chiauci, Civitella Alfedena), Calabria (Civita) or Sardinia (Castelsardo, Se-

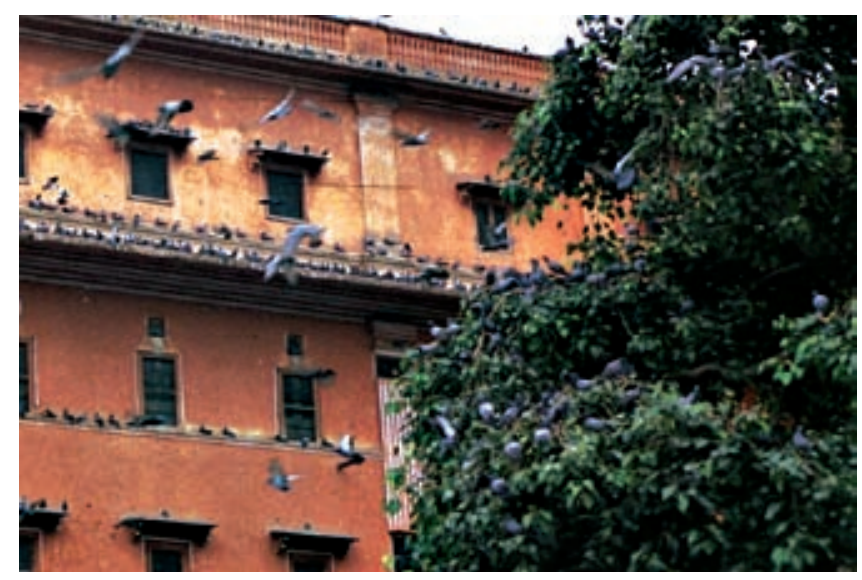

Fig. 1 - A picture from the inner city of Kathmandu (Nepal) showing a synanthropic colony of rock doves (Columba l. intermedia). / Colonia sinantropica di colombi selvatici (Columba l. intermedia) presente nella città di Kathmandu (Nepal). dini, Fertilia). In this latter village, only $12 \mathrm{~km}$ from the colonies of Capo Caccia, we were able to trap a group of 17 pigeons settled in the attic of an abandoned house; among them, from the point of view of the external features, 14 individuals were rock doves, while the others were ferals. This was the only time we were able to trap synanthropic individuals of rock doves and it may be the only one reported so far, except for the case reported by Alleva et al. (1975) regarding a similar occurrence in Chiauci. Today, the Fertilia village hosts a well-developed feral population, but Ragionieri et al. (1991) found that they were in an intermediate position between the rock doves of Capo Caccia and the ferals from the city of Sassari, according to a multivariate biometric analysis (Discriminant Function Analysis) (Fig. 2). Such a relationship may indicate a clear contribution of rock doves to the local populations of ferals in Sardinia.

As a further example, Ghigi (1950) indeed described the creation of the original nucleus of the feral populations in Bologna from dovecote pigeons that were to replace the synanthropic rocks that lived in the dome of the church of San Petronio. The same happened in the Cathedral of Florence in 1887 when a thousand of homing pigeons, released for the inauguration of its façade, failing to live up to their name, largely remained in the church and integrated with the still present synanthropic rocks, which were later assimilated by the homers and by other dovecote pigeons that arrived in the meantime, producing one of the first nucleus of Florentine ferals.

The same may have occurred in similar situations throughout the range of the wild rock dove, in particular, in the Mediterranean basin and the Near East, where the first domestic breeds of pigeons have historically been selected (Bodenheimer, 1960). In these countries the contribution of native rock doves to feral populations became a matter of fact. That contribution process concerns both the very beginning of their relationship history and also the subsequent times, in a endless fashion, at least until the rock dove gene pool will be completely introgressed

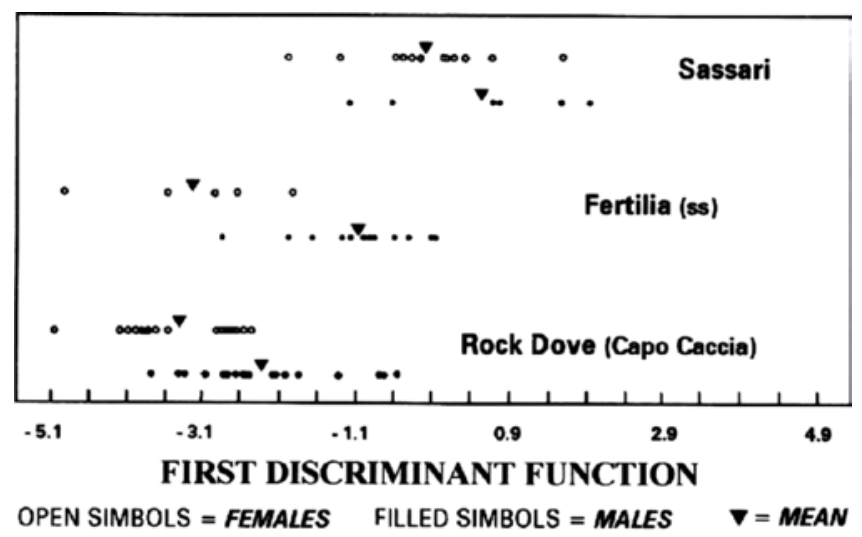

Fig. 2 - Position of male (filled symbols) and female (open symbols) pigeons belonging from a rock dove colony (Capo Caccia) and two feral populations (Fertilia, Sassari) on the basis of the First Discriminant Function. Triangles represented the mean values. (Modified after Ragionieri et al., 1991). / Posizioni relative di colombi maschi (simboli pieni) e femmine (simboli vuoti) di colombi selvatici di Capo Caccia e di due popolazioni di colombi di città provenienti da Fertilia e Sassari, ordinati in base alla prima funzione discriminante. I triangoli rappresentano il valore medio delle popolazioni. (Da Ragionieri et al., 1991, modificata). 
by the feral genes. Feral and synanthropic rock dove populations interact genetically and, to a lesser extent, ecologically. From an ecological point of view, they interact competitively with regard to nest sites but very seldom to rural feeding places and none in the urban habitat, given that rock doves have a very low tolerance of human activities (Savi, 1829; Johnston \& Janiga, 1995). Genetically, an important aspect of feral pigeons behaviour is their capacity for high annual reproductive success, breeding all year round (Johnson, 1984; Baldaccini, 2012), with respect to rock doves that produce only a first and eventually a second (or a replacement) clutch (data for Sardinia and, according to Thibault \& Bonaccorsi (1999), for Corsica Islands). This determines the greater success of ferals in any situation, allowing the feral populations to supersede rocks in a context situation, as reported by Ghigi (1950) in the very case of Florence or Bologna.

In the Middle East the presence of populations of synanthropic rock doves are always widespread also in large cities, though extralimitally with respect to feral populations that have not yet developed in those countries, as observed in different areas of Nepal and Pakistan (Baldaccini \& Tallone, 1995). Hopefully they will not develop in the near future, otherwise the genetic extinction of rock dove will be completed everywhere.

\section{FINAL REMARKS}

In Italy synanthropic populations of rock dove are not the founders of ferals populations, nevertheless they settled in urban habitats well before the constitution of the feral form of pigeons, according to late ornithologists such as Savi (1829), Salvadori (1873), Lucifero (1901) and Ghigi (1950). The turn of the $18^{\text {th }}$ and $19^{\text {th }}$ centuries may be indicated as the moment in which the feral populations were in established throughout Europe. At that time, the main source was represented by dovecote pigeons, when dovecotes were abandoned and sometimes destroyed as a sign of noble privilege; this happened in France at the time of Revolution (Van der Linden, 1950) and afterwards also in Northern Italy (Giachetti, 1894).

When the feral populations became frequent in cities, they came into contact with the already settled synanthropic rock doves, and because the interbreeding possibility between the two lineages, rock doves were assimilated by ferals and their gene pool diluted in those of the dominant ferals. This contribution to the feral gene pool started very early as soon as feral populations developed throughout the range of rock doves, and still continues today. So that feral populations originated not only from domestic breeds but also from synanthropic rocks doves of the different subspecies existing in this geographic range. This contribution has not been negligible in particular in the Southern parts of Italy and in the other Mediterranean and Near East countries, where the wild and synanthropic rock dove populations have been one of their geographic centres of gravity.

This means that the contribution of rock doves to the gene pool of feral populations is not a matter regarding past history, as represented by Johnston \& Janiga (1995; see fig.1.5) depicting in a tree diagram the genealogical relationships of rock doves, the domestics and the feral lineages. Instead, the genetic relationships between rock doves and the European ferals, in particular those of the Mediterranean basin, have been, and still are, continual. Today, ferals still have the opportunity of functionally joining wild rock doves as reproductive partners, at least in the proper sites where they are present. This provided for such ferals the opportunities to continuously incorporate genetic characters from their wild ancestors, as demonstrated by Johnston (1992b) for those regarding skeletal morphology.

It will be of interest, in future researchers, to ascertain the evidence of these relationships by a comparison of the genetic structure of feral populations developed far from or near by sites where colonies of wild rock dove are or have been present.

In conclusion, if we can observe a genetic flow from rock doves to ferals, on the other hand, a wide genetic intrusion of feral genes to rock doves is at work, responsible for the dissolution of the gene pool of the primordial form of wild pigeon, which has now almost reached completion in European countries. This fact is obviously of great conservation concern, as stated by Johnson et al. (1988) and more recently discussed by Boano et al. (2018).

\section{Acknowledgments}

Many thanks are due to Alberto Meriggi, Giovanni Boano, William Smith, Dimitri Giunchi for critically reading a first draft of the manuscript, contributing with useful suggestions to his improvement. Wendy Doherty edited the English while Daniele Santerini edited the figures.

\section{REFERENCES}

Alleva E., Baldaccini N. E., Foà A. \& Visalberghi E., 1975 - Homing behaviour of the Rock Pigeon. Monitore Zoologico Italiano, 9: 213-224.

Baldaccini N. E., 2003 - Piccione selvatico. In: Uccelli d'Italia. Spagnesi M. \& Serra L. (a cura di). Ministero dell'Ambiente e della Tutela del Territorio. Istituto Nazionale per la Fauna Selvatica. Quaderni di Conservazione della Natura, 16: 186-187.

Baldaccini N. E., 2012 - Uccelli ed industrie alimentari: un dissidio insanabile? In: La difesa antiparassitaria nelle industrie alimentari e la protezione degli alimenti. Cravedi P. (ed.). Chriotti Editori, Pinerolo: 24-37.

Baldaccini N. E., Delitala G., Mongini E. \& Ragionieri L., 1988 - La popolazione di Colombo selvatico (Columba l. livia $\mathrm{Gml}$ ) di Capo Caccia: notizie tassonomiche e comportamentali. Naturalista Siciliano, S. IV, XII (suppl.): 267-272.

Baldaccini N. E. \& Giunchi D., 2006 - Le popolazioni urbane di colombo: considerazioni sulla loro genesi e sulle metodologie di gestione. Biologia Ambientale, 20 (2): 125-141.

Baldaccini N. E., Giunchi D., Mongini M. \& Ragionieri L., 2000 - Foraging flights in the rock doves (Colunba l. livia): a spatiotemporal analisys. Italian Journal of Zoology, 67 (4): 371-377.

Baldaccini N. E., Giunchi D., Mongini M. \& Ragionieri L., 2001 - Release experiments with wild rock doves (Columba l. livia Gm.). Behaviour, 138: 923-936. 
Baldaccini N. E. \& Tallone G., 1995 - Attività ornitologica italiana in Pakistan (Himalaya e Karakorum). In: Atti del VII Convegno Nazionale di Ornitologia. Pandolfi M. \& Foschi U. F. (eds). Istituto Nazionale per la Fauna Selvatica. Supplemento alle Ricerche di Biologia della Selvaggina, 22: 349-351.

Biala A., Dybus A., Pawlina E. \& Proskura W. S., 2015 Genetic diversity in eight pure breeds and urban form of domestic pigeon (Columba livia var. domestica) based on seven microsatellite loci. Journal of Animal and Plant Sciences, 25: 1741-1745.

Boano G., Brichetti P., Cambi D., Meschini E., Mingozzi T. \& Pazzucconi A., 1985 - Contributo alla conoscenza della avifauna della Basilicata. Ricerche di Biologia della Selvaggina, 75: 1-35.

Boano G., Perco F., Pavia M. \& Baldaccini N. E., 2018 Columba livia forma domestica, entità invasiva aliena anche in Italia. Rivista Italiana di Ornitologia, 88 (2): 3-10.

Bodenheimer F. S., 1960 - Animal and man in bible lands. Brill, Leiden.

Bonaparte C. L., 1832 - Iconografia della fauna italica per le quattro classi degli animali vertebrati. Uccelli, vol. I, pars $2^{\text {nd }}$. Tipografia Salviucci, Roma.

Burley N., 1981 - Mate choice by multiple criteria in a monogamous species. The American Naturalist, 117 (4): 515-528.

Darwin C., 1868 - The variation of animals and plants under domestication. John Murray, London.

Ghigi A., 1950 - Piccioni domestici e colombicoltura. Ramo editoriale degli agricoltori, Roma.

Giachetti G. C., 1894 - Monografia dei piccioni domestici. Tipografia Operai, Milano.

Giunchi D., Mongini M., Pollonara E. \& Baldaccini N. E., 2003 - The effect of clock-shift on the initial orientatation of wild rock doves (Columba l. livia). Naturwissenschaften, 90: 261-264.

Giunchi D., Mucci N., Bigi D., Mengoni C. \& Baldaccini N. E., 2020 - Feral pigeon populations: their gene pool and links with local domestic breeds. Zoology, 142. <doi: 10.1016/j.zool.2020.125817>

Goodwin D., 1970 - Pigeons and Doves of the World. British Museum (Natural History), London.

Goodwin D., 1978 - Birds of man's world. Cornell University Press, Ithaca, N.Y.

Grüll A., 1980 - Columba livia. Strassentaube. In: Handbuch der Vögel Mitteleuropas. Vol. 9. U. Glutz von Blotzheim \& K. M. Bauer (eds.). Akademische Verlag, Viesbaden: 13-42.

Hoffman H., 1982-Das Taubenbuch. Kruger Verlag, Berlin.

Iapichino C. \& Massa B., 1989 - The birds of Sicily. Check-list No. 11. British Ornithologist's Union, Tring. U.K.

Janiga M., 1987 - Seasonal aspects of intensity and course of daily translocation of pigeons (Columba livia $\mathrm{f}$. domestica) for food from Bratislava to its surrounding. Acta Facultatis Rerum Naturalium Universitatis Comenianae. Zoologia, 32: 47-58.

Johnston R. F., 1984 - Reproductive ecology of the feral pigeon Columba livia. Occasional Paper Museum Natural History University of Kansas, 114: 1-8.
Johnston R. F., 1992a - Geographic size variation in rock pigeon, Columba livia. Bollettino di Zoologia, 59: 111-116.

Johnston R. F., 1992b - Evolution in the rock dove: skeletal morphology. The Auk, 109: 530-542.

Johnston R. F. \& Janiga M., 1995 - Feral Pigeons. Oxford University Press, Oxford.

Johnston R. F., Siegel-Causey D. \& Johnson S. G., 1988 European populations of the Rock Dove Columba livia and genotypic extinction. The American Midland Naturalist, 120 (1): 1-10.

La Gioia G. (ed.), 2009 - Atlante degli uccelli nidificanti in provincia di Lecce (2000-2007). Edizioni del Grifo, Lecce.

Lever C., 1987 - Naturalized birds of the world. Longman, Harlow, U.K.

Liuzzi C., Mastropasqua F. \& Todisco S., 2013 - Avifauna pugliese... 130 anni dopo. Dalla revisione della collezione Vincenzo De Romita alla realizzazione della nuova check-list. Edizioni Favia, Bari.

Lucifero A., 1901 - Avifauna Calabra. Elenco delle specie di uccelli stazionarie e di passaggio in Calabria. Tipografia Sordomuti, Siena.

Meschini E. \& Frugis S. (eds.), 1993 - Atlante degli Uccelli Nidificanti in Italia. Supplemento alle Ricerche di Biologia della Selvaggina, 20: 1-344.

Murton R. \& Clarke S., 1968 - Breeding biology of rock doves. British Birds, 61: 429-448.

Peronace V. Cecere J. G., Gustin M. \& Rondanini C., 2012 - Lista rossa 2011 degli uccelli nidificanti in Italia. Avocetta, 36: 11-58.

Ragionieri L., Mongini M. \& Baldaccini N. E., 1991 Problemi di conservazione in una popolazione di Colombo selvatico della Sardegna. Supplemento alle Ricerche di Biologia della Selvaggina, 18: 35-46.

Salvadori T., 1873 - Fauna d'Italia. Uccelli. Vallardi, Milano.

Savi P., 1829 - Ornitologia Toscana. Vol. II. Tipografia Nistri, Pisa.

Soldatini C., Mainardi D., Baldaccini N. E. \& Giunchi D., 2006 - A temporal analysis of the foraging flights of feral pigeons (Columba livia $\mathrm{f}$. domestica) from tree Italian cities. Italian Journal of Zoology, 73: 83-92.

Sossinka R., 1982 - Domestication in birds. Avian Biology, 6: 373-403.

Stringham S. A., Mulroy E. E., Xing J., Record D., Guernsey M. W., Aldenhoven J. T., Osborne E. J. \& Shapiro M. D., 2012 - Divergence, convergence, and the ancestry of feral populations in the domestic rock pigeon. Current Biology, 20: 302-308.

Thibault J-C. \& Bonaccorsi G., 1999 - The birds of Corsica. Checklist No. 17. British Ornithologist's Union, Tring. U.K.

Toschi A., 1939 - Ricerche ed osservazioni sul Colombo selvatico (Columba livia L.). Tipografia Compositori, Bologna.

Van der Linden F., 1950 - Le pigeon voyageur. Payot, Paris.

Visalberghi E., Foà A., Baldaccini N. E. \& Alleva E., 1978 - New experiments on the homing ability of the rock pigeons. Monitore Zoologico Italiano, (NS), 12: 199-209. 